\title{
Reducing Disturbance in Parking System by Using Quality Function Deployment (QFD) Method
}

\author{
Muhammad Ashlyzan Razik ${ }^{1}$, Noorshella Che Nawi ${ }^{1}$, Asrul Hery Ibrahim Dzulkifli Mokhtar ${ }^{1}$ \& Norlinda Mohd \\ $\operatorname{Rozar}^{1}$ \\ ${ }^{1}$ Faculty of Entrepreneurship and Business, Universiti Malaysia Kelantan, Malaysia \\ Correspondence: Muhammad Ashlyzan Razik, Faculty of Entrepreneurship and Business, Universiti Malaysia \\ Kelantan, Malaysia.
}

Received: May 1, 2019

doi:10.5430/rwe.v10n2p6
Accepted: June 1, 2019

Online Published: July 7, 2019

URL: https://doi.org/10.5430/rwe.v10n2p6

\begin{abstract}
This paper purposed is to apply Quality Function Deployment (QFD) for Parking System Improvement at Taman Bendahara from perspective of customers. The main issue for the QFD problem was from the 'what' the customer requirement and 'how' to implement the problem to solutions. These two components emphasized on the House of Quality (HOQ) matrices. For this research, a systematic procedure is used in QFD method by applying a factor analysis and correlation Spearman. Factor analysis is the best group identified from the data and reduced the unused items. As for the correlation Spearman, it was used in order to see the relationship and strength of each factor. The result in this research identified four best group criteria which are availability, layout and design, safety and access point. These four criteria indicate the main improvement needed for parking system. By using the QFD method, the management of parking system at Taman Bendahara should listen to the customers' voice to seek a solution for these issues. This study proposed strategy can be applied for others management to identify the solution for parking problems.
\end{abstract}

Keywords: Quality Function Deployment (QFD), House of Quality (HOQ), Parking System Improvement (PSI)

\section{Introduction}

Parking demand is a very critical issue in campus planning and developing especially to the campus that built in urban or town area which congestion is other issues that need to be take care of. With the increasing number of students each year has worsen this problem which has contribute to the increasing number of student with vehicles and the parking facilities definitely not enough to occupy each student attending the campus.

Parking is one of the critical issues in transportation, Campus and universities planning should involve parking as one of main important factor where it is to fulfil the requirement of demand parking due to high increase number of vehicle numbers (Ametorwo, 2016). Therefore, universities should begin to notice the problems and the importance of proper allocation of parking numbers for their students, staffs and visitors.

\section{Problem Statement and Study Objectives}

In University, parking system is one of the crucial facility for student and staff. If unable to handle the operations of parking spot will leads the parking spot to be congested. Moreover inefficiency of parking system will also cause dissatisfaction among student and staff. Obviously overwhelming numbers of cars and motorcycles leads congestion during "in and out" of cars and motorcycles at parking spot. Thus increasing in number of students and staff cannot meet up the demand of parking system (Aldulaimi, 2018). Therefore the University Malaysia Kelantan needs to design a layout for specific parking spot for students as well staff with appropriate parking standard. In particular, this study has two main objectives; 1 - to investigate the factors that affected the parking system improvement in UMK City Campus and 2- to determine the Parking System Improvement by using the Quality Function Deployment (QFD).

\section{Literature Review}

Quality function deployment (QFD) plays important part in product development process. QFD can be defined as a a key tool that emphasizes in translating customer requirements into the appropriate technical requirements (Chan \& Wu, 2002). QFD was introduced by Akao in the late 1960s and implemented in Japan. Based on Govers (1996), he 
proposed that QFD can help to develop products through the conceptualization, creation and realization process. It was used as powerful planning tools that help to improved product design and quality faster by focusing on customer requirements. Bouchereau \& Rowlands (2000) stated that, QFD could bring different functional teams to work together in order to satisfy the customer. The QFD concept focuses on two main activities which product quality deployment and deployment of quality function.

\section{Methodology}

The study of this research begins with an observation method. This method was implemented as it could provide any appropriate information on the requirement of student and staff from University Malaysia Kelantan: City Campus for standard parking system. Later the data collected from the observation is further studied to be used for the development of Quality Function Deployment (QFD). The purpose of developed QFD for our research is ascertain on question of what and how from towards the requirements of student and staff for standard parking system.

\section{Result and Finding}

\subsection{Questionnaire Distribution}

After questionnaire had passed the pilot test, questionnaire started to distribute to respondents to collect data and analyze. Researchers had distributed 145 set of questionnaire to respondents and data had collected. Reliability test has been tested too. Below are the table of reliability test for 145 set of questionnaire.

Table 1. Result of reliability test for whole questionnaire

\begin{tabular}{lll}
\hline Factor & Number of items & Cronbach's Alpha \\
\hline Parking issues & 5 & 0.618 \\
\hline Availability & 5 & 0.630 \\
\hline Layout Design & 5 & 0.626 \\
\hline Safety & 5 & 0.627 \\
\hline Access Point & 5 & 0.711 \\
\hline
\end{tabular}

Based on the table above, Cronbach's Alpha of each of the variables had shown by calculated 145 respondent's data. Among these factors, dependent variable - Parking issues have a reliability level of 0.618 which had decrease from 0.670. Yet, the independent variable - Safety, has turn to become 0.627 while Access Point has become the highest reliability level which is 0.711 . Lastly, the independent variables of Availability and Layout Design have decrease to a reliability level of 0.630 and 0.626 respectively.

\section{Dividing Section}

This section is divided into two main sections which is WHAT and HOW. What analysis involves the analysis of items processed using factor analysis and grouped in several groups of constructs. As shown in Figure 5.2 WHAT's was divided to two group, $\mathrm{X}$ and $\mathrm{Y}$ and comes from four main construction a group consisting of factor Availability (AV), Safety (SV), Layout Design (LD) and Access Point (AP).Groups of these factors were what was agreed upon by all Malaysian parking users on what to have for Parking System Improvement (PSI).

HOW' is a group of items involved in the technical aspects of a parking standard. It was agreed aspects of the 10 elements on the technical aspects that were required for PSI (Ali \& Haseeb 2019). In this study there were 10 technical aspects discussed consisting of stalls dimension, aisle width, signage, marking, handicap parking, safety mirror, space, angle, parking pricing, parking size (Altunkaya \& Ates 2018). 


\section{Model Development}

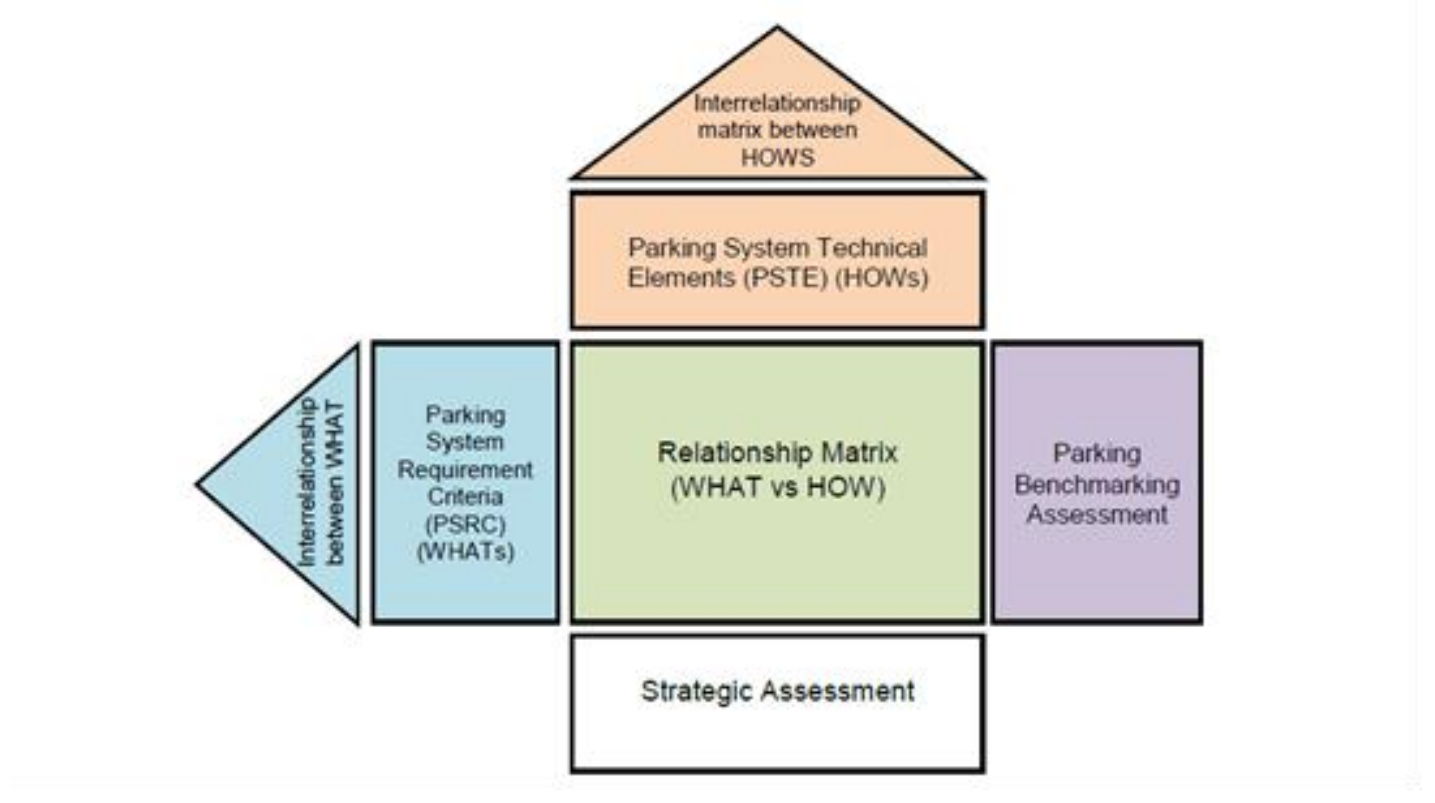

Figure 1. Model Development for Quality Function Deployment (QFD)

Figure 1 shows the proposed modified QFD model. There are 7 rooms in these proposed models; Room 1 Parking System Requirements (PSR) (WHATs), Room 2 Parking System Technical Elements (PSTE)(HOWs), Room 3 Relationship Matrix, Room 4 Develop interrelationship matrix between HOWs, Room 5 Develop an interrelationship between WHAT, Room 6 Parking Benchmarking Assessment and Room 7 Strategic Assessment. In this proposed model, the Factor Analysis used to firm priority from the items (Almasi \& Khorasgani 2018). It also used to eliminate the unused items. The spearman correlation was employed to identify the relationship between them.

\section{Discussion}

This study provide proposed solutions to resolve on- campus parking. Vehicle stacking is a mechanical parking solution implemented to enables multiple vehicles parked in the footprint of a single vehicle. Before suggestion given, there are few method that could be suggested to the future researchers who want to do research about parking system. First, interview question could be fully processed since the objective questionnaire could not bring accurary result due to the simplyness respondents (Ale, Akter \& Islam 2018). Yet, QFD method could be implemented to be more complex to get more detail about parking system improvement.

Lastly, according the result which are the stall dimension, parking size, line of parking lots, floor marking and lighting was the main issue that should be improve in order to get a better parking system Taman Bendahara, researchers were recommended to implement more lighting around the parking area.This solution considered as a potential method for increasing on-campus parking spaces and this type of technology is merely appropriate for use in parking decks. The parking structures could be designed to accommodate vehicle stackers, still technology required well trained operators to make it suit for valet parking.

\section{References}

Aldulaimi, S. H. (2018). The Influence of National Culture on Commitment that Produce Behavioral Support for Change Initiatives. International Journal of Applied Economics, Finance and Accounting, 3(2), 64-73. https://doi.org/10.33094/8.2017.2018.32.64.73

Ale, S. A., Akter, R., \& Islam, M. S. (2018). Remittance Inflow and GDP Growth: Evidence from Bangladesh, India and Pakistan. Asian Economic and Financial Review, 8(11), 1340-1353. https://doi.org/10.18488/journal.aefr.2018.811.1340.1353

Ali, A., \& Haseeb, M. (2019). Radio frequency identification (RFID) technology as a strategic tool towards higher performance of supply chain operations in textile and apparel industry of Malaysia. Uncertain Supply Chain 
Management, 7(2), 215-226. https://doi.org/10.5267/j.uscm.2018.10.004

Aliran, S., \& Dalaman, T. (2014). Guidelines Internal Traffic Circulation, 1982(Akta 267), 1-13.

Almasi, N., \& Khorasgani, N. S. (2018). Investigation of the Relationship Between Emotional Intelligence and Effectiveness of Educational Administration in City of Isfahan. Humanities \& Social Sciences Reviews, 6(1), 19-24. https://doi.org/10.18510/hssr.2018.614

Almeslati, A. I., Rahmat, R. A. O. K., Jaafar, O., \& Abuhamoud, M. A. (2011). The rise of the private car usage in Kajang, Malaysia: role of parking policy on reducing car usage. Journal of Applied Sciences Research, 7, 1263-1268.

Altunkaya, H., \& Ates, A. (2018). Sources of Reading Anxiety among the Learners of Turkish as a Foreign Language. Asian Journal of Education and Training, 4(3), 161-169. https://doi.org/10.20448/journal.522.2018.43.161.169

Ametorwo, A. M. (2016). Managing Work Family Conflict among Female Entrepreneurs in Ghana for Development. International Journal of Economics, Business and Management Studies, 3(1), 21-35.

Barter, P. A. (2010). Parking Policy in Asian Cities. SSRN Electronic Journal. https://doi.org/10.2139/ssrn.1780012

Batabyal, A. A., \& Nijkamp, P. (2009). A probabilistic analysis of two university parking issues. Annals of Regional Science, 44(1), 111-120. https://doi.org/10.1007/s00168-008-0237-8

Bouchereau, V., \& Rowlands, H. (2000). Methods and techniques to help quality function deployment (QFD). Benchmarking: An International Journal, 7(1), 8-20. https://doi.org/10.1108/14635770010314891

Bowerman, A. K. (2006). On-Campus Parking: Problems and Solutions.

Caicedo, F. (2009). The use of space availability information in "PARC" systems to reduce search times in parking facilities. Transportation Research Part C: Emerging Technologies, 17(1), 56-68. https://doi.org/10.1016/j.trc.2008.07.001

Caicedo, F., Blazquez, C., \& Miranda, P. (2012). Prediction of parking space availability in real time. Expert Systems with Applications, 39(8), 7281-7290. https://doi.org/10.1016/j.eswa.2012.01.091

Chan, L.-K., \& Wu, M.-L. (2002). Quality function deployment: A literature review. European Journal of Operational Research, 143. https://doi.org/10.1016/S0377-2217(02)00178-9

Chen, M., Hu, C., \& Chang, T. (2011). The research on optimal parking space choice model in parking lots. ICCRD2011 - 2011 3rd International Conference on Computer Research and Development, 2, 93-97. https://doi.org/10.1109/ICCRD.2011.5764091

Crowder, M., Walton, C. M., \& River, R. (2003). Developing an Intelligent Parking System for the University of Texas at Austin.

Govers, C. P. M. (1996). What and how about quality function deployment (QFD). Int. J. Production Economics, 46-47(95), 575-585. https://doi.org/10.1016/0925-5273(95)00113-1

P.Seng. (2011). Parking effic. Parking Efficient Parade Ump, Perpustakaan, (May).

Razik, M. A., Tahar, R. M., Hasrulnizzam, W., Mahmood, W., \& Rozar, N. M. (2015). Index Terms-Quality function deployment (QFD), dry bulk terminal improvement (DBTI), house of quality (HOQ). Integrated Quality Function Deployment (QFD) Model for Dry Bulk Terminal Improvements (DBTI) in Malaysian Ports. Journal of Economics, Business and Management, 3(4), 4-7. https://doi.org/10.7763/JOEBM.2015.V3.219

Rome, P., \& Mukherjee, S. (2015). Car Parking - A Perennial Problem of Kolkata. International Journal of Science and Research, 4(6), 2583-2587.

Stubbs, M. (2002). Car Parking and Residential Development: Sustainability, Design and Planning Policy, and Public Perceptions of Parking Provision. The Round Table, 7(2), 213-237. https://doi.org/10.1080/1357480022000012249

Tapke, J., Muller, A., Johnson, G., \& Sieck, J. (1997). House of Quality. Steps in Understanding the House of Quality.

van Wyk, B. ( D. (n.d.). Research design and methods Part I, 16.

Zaim, S., \& Şevkli, M. (2002). The Methodology of Quality Function Deployment with Crisp and Fuzzy Approaches and an Application in the Turkish Shampoo Industry. Journal of Economic \& Social Research, 4(1), 27-53. 